\title{
O "WYPOŻYCZANIU" CIAŁ ODBIORCÓW NA POTRZEBY (NIE TYLKO LITERACKICH) IMMERSYJNYCH WECDRÓWEK PO PRZESTRZENIACH PAMIĘCI
}

On "Borrowing" Readers/Users Bodies for Immersion into the (Not Only Literary) Memory Spaces

\begin{abstract}
The aim of this article is to study (mainly but not only) literary works that "borrow" users/readers bodies in order to create immersive memory spaces, i.e. that engage haptic interactions with texts as the sine qua non of entering the narrated story-worlds. To depict the broader context authors characterize the general strategy of immersion based on haptic experience of the work (metaphorically described as "borrowing of the user's body"), seen in various media and different forms of storytelling, from traditional literary second person narratives to VR/XR experiences. Then authors focus on two e-literary examples (WuWu\&Co and Maginary) in order to analyze how the reader's gestures or his/her whole body can be incorporated into the act of reading. The purpose of introducing aforementioned case-studies is to point out the importance of elaborating actual discussions on haptic poetics of e-literary works. The paper ends with a close reading of Pry (by Samantha Gorman and Danny Cannizzaro), the case study that provides a perfect example of "borrowing e-reader's body" in order to immerse him/her in the memory space that is co-created by the protagonist's memories and the reader's gestures.
\end{abstract}

Keywords: Pry, WuWu\&Co, Maginary, haptic poetics, reading gestures, immersive memory spaces, playable memory, e-literature 


\section{Wynajmowanie ciała dla cudzych wspomnień, czyli haptyczne doświadczenia przeszukiwania strychu pamięci}

Opisując interakcję z Immemory Chrisa Markera, tekstu, który był „w swoim czasie [...] idealnym wprost medium demonstracji pracy pamięci" ${ }^{1}$, Catherine Lupton stwierdziła, że nawigowanie po nim:

[...] jest dokładnie tym, czym szperanie w skarbach ukrytych na wirtualnym poddaszu... czas zatrzymuje się, a Ty zatracasz się, ślęcząc nad przypadkowymi, zapomnianymi pamiątkami z przeszłości, które unoszą się ku powierzchni, gdy zanurzasz w nie ręce/sięgasz po nie².

W oddawanym w ręce czytelników numerze „Przeglądu Kulturoznawczego" przyglądamy się tekstom kultury, które oferują podobne doświadczenia, lecz urealniają je, wzmacniając immersję przez traktowanie nie wyłącznie urządzeń wejścia/ wyjścia, lecz i samego ciała odbiorcy jako niezbędnego (i często jedynego) narzędzia do zanurzania się we wspomnienia. Ikoniczną reprezentacją interesujących nas strategii (i immanentnie wpisanej w nie haptyczności ${ }^{3}$ ) wydaje się przepracowująca kategorię pamięci kolektywnej praca Adriany Moreno SandBox - Grains in Memory ${ }^{4}$. Jej użytkownik, dopiero zanurzając ręce w zebrany w przezroczystym pojemniku piasek ${ }^{5}$, grzebiąc w nim, „odnajduje” wspomnienia - kiedy jego ręce zbliżają się do ukrytych na dnie ,piaskownicy” sensorów, system automatycznie

B. Kita, Refleksje o fotografii w twórczości Chrisa Markera, „Przegląd Kulturoznawczy” 2019, nr 1(39), s. 19.

2 C. Lupton, Chris Marker: Memories of the Future, Reaktion Books, London 2005, s. 37. Cytaty z dzieł obcojęzycznych w thumaczeniu autorek, chyba że zaznaczono inaczej. Por. B. Kita, Immemory (1997) Chris Marker, w: Klasyczne dzieła sztuki nowych mediów, red. P. Zawojski, Instytucja Kultury Katowice - Miasto Ogrodów, Katowice 2015, s. 105-110.

3 Haptyczności nie utożsamiamy tu z samą tylko taktylnością (odsyłającą jedynie do dotyku dłoni), podobnie jak Josephine Machon, traktując ją jako odnoszącą się do całego „performującego/ percypującego, zmysłowego ciała”. Jak wyjaśnia badaczka: „»Haptyczny« podkreśla dotykowe doznania percepcyjne całego ciała (a nie tylko palców), a także uwypukla zdolność postrzegania związaną z kinestetyką ciała (ruchem ciała w przestrzeni), która obejmuje propriocepcję (stymulację wytwarzaną i postrzeganą przez ciało w zależności od jego pozycji i ruchu). Percepcja haptyczna obejmuje wrażenia zmysłowe poruszającego się ciała oraz doświadczenie percepcyjne płynące dlań z poruszania się innych ciał" (J. Machon, Immersive Theatres: Intimacy and Immediacy in Contemporary Performance, Palgrave Macmillan, London 2013, s. 283).

$4 \quad$ Wchodzaca w skład projektu Grains of the Sea: Place of Identities and Memories Immersed in Sensory Interactive Experience praca prezentowana była na festiwalu Ars Electronica w 2019 roku w otoczeniu wielu innych projektów pozwalających na haptyczną i interaktywną eksplorację narracji wspomnieniowych, np. Knotting the Memory//Encoding the Kipu Patricii Cadavid czy Wondering Gaze Any Teresy Vicente.

5 Bezbarwna, w pełni neutralna i znikająca z pola obserwacji „piaskownica” wzmaga możliwość identyfikacji piasku z piaskiem dowolnej z przywoływanych we wspomnieniach nadmorskich plaż. 
uruchamia fragmentaryczne wspomnieniowe narracje audio ${ }^{6}$. Jeśli odbiorca nie zdecyduje się użyć własnego ciała jako swoistego klucza otwierającego dzieło praca pozostanie dlań niema, opowieść się nie zdarzy (nie będzie też jej można współtworzyć) $)^{7}$.

Istotę tak zaprojektowanej interakcji trafnie charakteryzuje metafora ,wynajmowania ciała" odbiorcy na potrzeby opowieści. Zaczerpnęłyśmy ją ze spektakli Rimini Protokoll: Call Cuta (2005), którego widz słyszy na początku performatywnego spektaklu-spaceru: „Ty mi wynajmujesz ciało, ja ci wynajmuję wspomnienia”, oraz Situation Rooms (2013)9, w którym pada skierowane do uczestnika zdanie: „Spójrz w lustro. Jestem hakerem. Teraz mam inne ciało, twoje" ${ }^{10}$. Zapraszając autorów do współpracy przy tym numerze, stawiałyśmy w gruncie rzeczy pytania o to, jak takie „wypożyczenia” mogą wyglądać i być artystycznie wykorzystywane w tekstach realizowanych w różnych mediach i w różnych (niekończenie artystycznych) strukturach narracyjnych. Interesowało nas także przejście od wyobraźniowego, umownego angażowania ciała odbiorcy (którego przykładem jest dla nas literacka narracja drugoosobowa $^{11}$ ) do coraz bardziej dosłownego traktowania realnego ciała jako narzędzia immersji ${ }^{12}$. Proponowałyśmy więc namysł i nad tekstami, w których wykorzystuje

6 Interaktor ma też możliwość rozbudowania wyjściowej bazy, dodania własnego nagrania. O charakterystycznych dla odbioru tego typu realizacji napięciach między nurzaniem się w cudzych wspomnieniach a aktywowaniem wspomnień własnych zob. M. Górska-Olesińska, Pamięć (wspót)doświadczana $i$ (wspót)tworzona - partycypacyjne i cielesne wymiary doświadczenia VR (,,Queerskins: A Love Story Illyi Szilak i Cyrila Tsinoulskiego) [w tym numerze].

7 Takie cielesne uwiązanie otwiera również szerokie pole dla (roz)grywalności tego typu doświadczeń, o czym będziemy jeszcze pisać.

8 Cytujemy na podstawie dokumentacji dostępnych na stronach autorów.

$9 \quad$ Polski widz mógł doświadczyć polskojęzycznej wersji projektu w listopadzie 2016 roku.

10 Cytujemy na podstawie dokumentacji dostępnych na stronach autorów.

11 Jednak analogicznie można by traktować ciało klasycznego widza. Por. B. Kita, Między przestrzeniami. O kulturze nowych mediów, Rabid, Kraków 2003.

12 Po części mówimy więc i o obszarze, który można by określić mianem haptycznej poetyki odbioru dzieła sztuki, zwłaszcza nowomedialnej. Można zatem powiedzieć, iż zebrane w tym numerze teksty poniekąd uzupełniają lukę wskazywaną przez Magdalenę Rembowską-Płuciennik w szkicu Po(d)taczeni. Empiryczne badania nad odbiorem literatury wobec odbioru cyfrowego, „Teksty Drugie” 2019, nr 5. Badaczka ta podkreśla, że „o ile poetyka, narratologia intermedialna czy transmedialna rozwijają się efektywnie, o tyle badania nad specyfiką procesów odbiorczych związanych z nowymi mediami są nadal rzadkie". Naszym zaś zdaniem nie należałoby tych obszarów aż tak wyraźnie rozgraniczać, choćby dlatego, że empiryczny odbiór tekstu winien być nieraz uwzględniany jako element jego poetyki (jak dzieje się np. w przypadku formułowania teorii figur gestów czytelnika i jak próbujemy czynić w prowadzonych w tym szkicu analizach). Jak podkreśla sama Rembowska-Płuciennik, „haptyczny składnik hiperlektury” (który badaczka wiąże niemal głównie z „koniecznością fizycznego wykonywania konkretnych operacji na klawiaturze/ekranie/interfejsie”) „zostaje wyraziście wzmocniony w stosunku do obcowania z materialnością książki kodeksu [...], bo dotyk i kinetyka właśnie stają się modalnościami technologicznie znaczącymi” (s. 272). Jednocześnie w pracach, jakie nas interesują, rzadko można doświadczyć wskazywanego przez badaczkę wyrzucenia z immersji (,,rozproszenia uwagi”), spowodowanego podwójnością odniesień zaimka 
się drobne, nieraz symboliczne, gesty, i nad pracami, w które zanurzamy się całym ciałem (czasem i po to, by w ich obrębie działać) $)^{13}$.

Szczególnie zainteresowała nas transmedialna perspektywa związana z estetyką haptyczności i angażowaniem w akt odbioru cielesności odbiorcy. Próba lokowania go wewnątrz świata, proponowania mu poznania poprzez działanie, poznania nie teoretycznego, zakładającego zewnętrzną zdystansowaną perspektywę jakiegoś, odsłaniającego prawdy absolutne, ,,mentora”" świadczeniu i eksploracji - to strategia twórcza, którą odnajdujemy we wszystkich mediach (choć każde z nich używa własnych środków) ${ }^{15}$. Klasyczna literacka narracja drugoosobowa (zwłaszcza prowadzona w czasie teraźniejszym) ${ }^{16}$, określana jako „ostatni ważny eksperyment w zakresie literackich reprezentacji świadomości bohatera" ${ }^{17}$, nim przez powieści paragrafowe i role-playing games weszła do świata (roz)grywalnych nowomedialnych opowieści, z powodzeniem była wykorzystywana do przedstawiania punktu widzenia „innego”, zwłaszcza w kontekście różnego rodzaju atrofii i ułomności ${ }^{18}$, także tych związanych z problemami z pamięcią. Analogiczny rezultat można uzyskać w technologii VR (czy M/XR), jednak już nie dzięki symulacyjnemu jedynie wyobrażaniu sobie doznań „innego”, lecz możliwo-

„ja” czy „ty” z narracji bądź koniecznością świadomej obsługi interfejsu, gdyż nie tylko realnie a nie umownie - angażują one ciało odbiorcy, ale też czasami (rzeczywiście, w przeciwieństwie do klasycznego hipertekstu) posługują się interfejsami intuicyjnymi, niewidzialnymi, przezroczystymi, magicznymi (takimi, o jakich pisała m.in. Lori Emerson). Jednocześnie, jeśli jest obecne, napięcie charakteryzowane przez Rembowską-Płuciennik bywa również w interesujących nas dziełach twórczo przepracowane (co postaramy się podkreślić w analizach Pry).

13 Choć nie znalazły się w tym numerze szkice poruszające te kwestie, warto na pewno byłoby zanalizować w tym kontekście nie tylko klasyczne prace VR, ale także „analogowe” lub technologicznie poszerzone wystawy typu site-specific (np. fragmenty wystawy z gdańskiego Muzeum II Wojny Światowej replikujące w eksplorowalnej formie przedwojenną Warszawę).

14 Mówiąc najprościej - mamy tu na myśli różnomedialne odpowiedniki narratora wszechwiedzącego, będącego bezpiecznym gwarantem sensu.

15 W proponowanej transmedialnej perspektywie istotne jest dla nas również podkreślanie, że nie mamy do czynienia z drastycznym przełomem, lecz z udoskonalaniem dostępnych narzędzi (dość wspomnieć sensoramę czy teatr totalny).

16 Mamy tu na myśli to, co Brian Richardson określił jako jej „standardową” odmianę. Zob. B. Richardson, "At First You Feel a Bit Lost": The Varieties of Second Person Narration, w: idem, Unnatural Voices. Extreme Narrations in Modern and Contemporary Fiction, Ohio State University Press, Columbus 2006, s. 18.

17 M. Rembowska-Płuciennik, O przechodzeniu na ty... Narracja diadyczna wśród literackich reprezentacji świadomości bohatera, w: (W) sieci modernizmu. Historia literatury-poetyka-krytyka. Prace ofiarowane Włodzimierzowi Boleckiemu, red. A. Kluba, M. Rembowska-Płuciennik, Instytut Badań Literackich PAN, Warszawa 2017, s. 249.

18 Przykładem stawiającym tekstowe „ty” w roli niewidomej dziewczynki jest wielokrotnie analizowane opowiadanie Rumer Godden You Need to Go Upstairs. Por. M. Rembowska-Płuciennik, O przechodzeniu na ty... oraz eadem, Second-person Narration: A New Mode of (Mis) Understanding the Other?, w: Culture - Cognition - Communication, eds. J. Hood, Peter Lang, Frankfurt am Main 2018. 
ści wielozmysłowego cielesnego zanurzenia w świat opowieści. Beholder VR Matta Clarka, reprezentujący w miarę klasyczny (choć nierealistyczny) tzw. cinematic VR, umożliwia „zobaczenie od środka” autyzmu. Manic VR Kaliny Bertin pozwala „poczuć" własnymi zmysłami chorobę dwubiegunową, a w doświadczeniu tym kluczowa jest właśnie możliwość interakcji19 (a konkretniej - podporządkowana stadiom choroby - utrata tej możliwości) ${ }^{20}$. Interakcja jest kluczowa również w odbiorze poruszającej pracy Cosmos within Us Tupaca Martira, która sytuuje nas w umyśle sześćdziesięcioletniego mężczyzny chorującego na chorobę Alzheimera ${ }^{21}$. W każdym z tych przypadków podstawą doświadczenia jest właśnie założenie, że na potrzeby opowiedzenia (i doświadczenia) historii „wynajęte” zostanie wyobrażone lub realne ciało odbiorcy ${ }^{22}$.

Otwierając te rozważania, chciałyśmy pójść tropem tak rozumianej transmedialnej haptycznej narratologii i przyjrzeć się „wypożyczaniu” ciał (e-)czytelników. Tak jak Magdalena Rembowska-Płuciennik widzi w narracji prowadzonej w drugiej osobie, włączającej czytelnika w świat przedstawiony, ,rodzaj pomostu nad, zdawałoby się, nieprzekraczalną granicą między pierwszoosobową perspektywą działającego i trzecioosobową perspektywą obserwatora" ${ }^{23}$, tak my podobny potencjał dostrzegamy właśnie w realnym, dosłownym angażowaniu w akt odbioru ciała czytelnika, czy to w stopniu nikłym i często symulacyjnym (poprzez gesty), czy też w zdecydowanie głębszym, na drodze umożliwienia percepcji świata opowieści wszystkimi zmysłami (w przypadku pełnej cielesnej immersji). W odniesieniu do klasycznych werbalnych narracji literackich możemy za Markiem Caracciolo, przywoływanym przez badaczkę, mówić o tym, że działają one jak ,maszyny do wzbudzania doświadczenia obsługiwane instrukcją »wyobraź sobie, że...«"24, iż są ,językowo ukonstytuowanym medium do imaginacyjnego powielenia (odegrania, wzbudzenia, przywołania) cudzego

19 Wprowadzenie interakcji powoduje aktywowanie w procesie odbioru jeszcze większej liczby zmysłów: o ile cinematic VR bazuje na doświadczeniach widzianych, słyszanych, o tyle tu dodatkowo mamy też wszystko, co związane z gestami, na których oparta jest interakcja.

20 Wszystkie te realizacje warto byłoby też rozpatrzyć w kontekście różnych wzmagających immersję zabiegów, stosowanych w różnym stopniu w werbocentrycznych narracjach literackich obrazujących specyfikę autystycznego bądź - inaczej - znaczonego chorobą percypowania i strukturyzowania świata. Mamy tu na myśli takie prace jak choćby: Pająk Patricka McGartha (zwłaszcza w zestawieniu z pracą Mój brat huragan Kolet Janssen), Wotga przez afazję Karoliny Wiktor czy Dziwny przypadek psa nocna porą Marka Haddona (nie wspominając już o Faulknerowskiej klasyce).

21 Ta angażująca ciało odbiorcy do rozważań o utracie pamięci praca, nagrodzona m.in. na ostatnim Biennale w Wenecji czy Raindance Film Festival (jej podtytuł to Memory Is All We Have), byłaby też idealnym case study w tym numerze, szczerze żałujemy, że tak się nie stało.

22 Szczegółowe analizy tych prac, przekraczające niestety ramy naszego opracowania, ukazałyby też, jak różnorodne struktury narracyjne wykorzystano na potrzeby kreowania tych doświadczeń (szczególnie widoczne jest to w Manic VR, będącym zresztą - przypomnijmy - częścią wielomedialnego projektu o autobiograficznym charakterze).

23 M. Rembowska-Płuciennik, O przechodzeniu na ty..., s. 260.

24 Cyt. za: ibidem, s. 261. 
doświadczenia"25. Teksty, które są przedmiotem analiz zarówno w tym szkicu, jak i w całym oddawanym w ręce czytelników numerze „Przeglądu Kulturoznawczego”, dążą do innej instrukcji - nie każą odbiorcom wyobrażać sobie, lecz: percypować, działać, czuć i doświadczać26. Zdaniem Rembowskiej-Płuciennik wyraźnie odżywająca $\mathrm{w}$ erze nowomedialnych narracji interaktywnych narracja drugoosobowa „sprzyja postawieniu się realnego czytelnika w czasoprzestrzeni akcji i mentalnej symulacji działań bohatera, do którego kierowana jest narracja: skanowania przestrzeni, zmyslowego jej odczucia, doznawania jako świata opowieści” ${ }^{27}$. Literackie (i okołoliterackie) teksty, które chciałybyśmy poddać analizie, wprowadzając do dyskusji o immersyjnych przestrzeniach pamięci, pozwalają zaś odbiorcy doświadczać „haptycznej symulacji”, mniej lub bardziej realnie (tj. przez symulacyjny gest lub wielozmysłowe cielesne zanurzenie) doświadczać tego, co w przypadku klasycznych literackich tekstów narracyjnych musiałby sobie (jedynie) wyobrażać. Takie doświadczenie opowieści może mieć charakter (roz)grywalny, a nawet i partycypacyjny, dlatego będziemy mówić o (roz)grywalnej pamięci pod palcami czytelnika czy ucieleśnionej pamięci (współ)doświadczanej.

\section{Wypożyczane na potrzeby literackich opowieści ciała czyłelników}

Zanim przyjrzymy się uważniej Pry Samanthy Gorman i Danny’ego Cannizzaro, które traktujemy jako doskonałą egzemplifikację haptycznych immersyjnych przestrzeni pamięci, chciałybyśmy zasygnalizować, jak w ogóle można w werbocentrycznych opowieściach dosłownie, a nie jedynie wyobrażeniowo, włączać ciało czytelnika w narrację (niekoniecznie drugoosobowa), „wypożyczać” je na potrzeby opowieści. Przywołane tu przykłady traktujemy jako exempla nowomedialnej literatury haptycznej, do której opisywania narzędzi próbuje dostarczać odświeżana poetyka, włączająca w obszar swoich badań m.in. czytelnicze gesty ${ }^{28}$, poetyka, w ramach której widziałybyśmy miejsce nie tylko na namysł nad dotychczas opisywanym gestycznym wymiarem lektury ${ }^{29}$, lecz i tym, co określiłybyśmy mianem lektury haptycznej, a co wiążemy z dosłownym, polisensorycznym cielesnym zanurzeniem odbiorcy $\mathrm{w}$ tekst ${ }^{30}$.

25 Ibidem.

26 W niektórych z tych prac - podobnie jak w przywołanym SandBox - Grains in Memory.

27 M. Rembowska-Płuciennik, O przechodzeniu na ty..., s. 261, podkreślenia - M.G.-O. i A.P.

28 Por. np.: S. Bouchardon, Figures of Gestural Manipulation in Digital Fictions, w: Analyzing Digital Fiction, eds. A. Bell, A. Ensslin, H.K. Rustad, Routledge, New York 2014 lub E. Szczęsna, Cyfrowa semiopoetyka, IBL PAN, Warszawa 2018.

29 S. Bouchardon, Mind the Gap! 10 Gaps for Digital Literature?, „Electronic Book Review” 2019, May 5, http://electronicbookreview.com/essay/mind-the-gap-10-gaps-for-digital-literature/(dostęp: 1.06.2019).

30 Por. też tekst Agnieszki Przybyszewskiej o „czytaniu kinetycznym”. A. Przybyszewska, Po(d)żeranie tekstu. Wstęp do rozważań o czytaniu kinetycznym, w: e-polonistyka 3, red. A. Dziak, A. Kopacz, Wydawnictwo KUL, Lublin 2016. 
E-literackie teksty o werbalnej dominancie, projektowane na urządzenia mobilne i nakładające światy opowieści na przestrzenie, w których przebywa ich odbiorca, opowieści w rodzaju wielokrotnie nagradzanego $W u W u \& C o^{31}$ czy niesłusznie dotąd niedocenianego Maginary Semyona Polyakovskiy'ego, nie korzystają wprost z obiecujących struktur narracji drugoosobowej, choć „wypożyczają” ciała odbiorców na potrzeby opowieści, włączając czytelników w świat przedstawiony. Na tych właśnie przykładach pokrótce pokażemy, jak nowe technologie pozwalają rozszerzyć spektrum narzędzi służących kreowaniu literackich immersyjnych doświadczeń (włączających realne ciało czytelnika w proces lektury).

Zespalająca klasycznie zapisany tekst z ruchomym obrazem w technologii 360 stopni $W u W u \& C o$ to adresowana do dzieci aplikacja książkowa (bookapp) w technologii step-in-book, przemieniającej - jak pisał Thomas Vigild - ekran, na którym czytamy, w „rodzaj magicznego lustra pozwalającego wkroczyć do świata opowieści” ${ }^{2}$. Możemy w niej wskazać pewnego rodzaju „wyrwy” narracyjne otwierające tekstowy świat na wejście czytelnika. Trzecioosobowa, wszechwiedząca narracja w kilku miejscach (konsekwentnie i celowo) ustępuje bowiem miejsca drugoosobowej, o wyraźnym charakterze apostroficznym. Te bezpośrednie zwroty do czytelnika (ograniczone do jednego - dwóch zdań nakazujących zmienić ułożenie czytnika i pomóc bohaterom) towarzyszą wszystkim fragmentom przejścia w tryb „lektury niewerbalnej”. Ta opiera się na interakcji ${ }^{33}$, wtedy bowiem tekst na ekranie zastępuje dynamiczny i zależny od działań widza obraz ${ }^{34}$. Narrator zawiesza wtedy swoją wszechwiedzę i oddaje poznanie świata (oraz dalsze losy bohaterów) w ręce (a także oczy i uszy) czytelnika. Znika nie tylko ten, kto opowiada ${ }^{35}$, ale i pośredniczący w przedstawianiu powieściowego świata fokalizator. A właściwie sam czytelnik, przynajmniej na chwilę, staje się fokalizatorem opowieści (raczej nie ekstradiegetycznym). Widać to niezwykle wyraźnie w otwierającej scenie, gdy - dzięki temu, że mamy do czynienia z animacją 360 stopni - tym, kto rozgląda się po będącej centrum świata przedstawionego przestrzeni Czerwonego Domu, jest właśnie sam czytelnik ${ }^{36}$.

31 Więcej o tej pracy zob. A. Przybyszewska, Literacka immersja i technologia step-in-book, czyli o przenikaniusięświatów literackich irzeczywistych, w: Nowoczesne technologie czy tradycyjne metody? O tendencjach w krzewieniu kultury czytelniczej młodego pokolenia, red. M. Antczak, A. Walczak-Niewiadomska, WUŁ-SBP, Łódź-Warszawa 2017.

$32 \mathrm{Z}$ materiałów promocyjnych dostępnych na stronie www.stepinbooks.com (dostęp: 30.06.2016).

33 Jej zakończenie zawsze sygnalizowane jest słowami „Opuść swój czytnik”, a zastosowanie się do tego polecenia pozwala wrócić do klasycznej lektury tekstu.

34 Dzieje się tak w finale każdego z rozdziałów, kiedy bohaterowie, dawszy czytelnikowi czas na przeczytanie ich historii, oczekują, że ten - już ją znając - podejmie się działań, które im pomogą.

35 Nie jest to jednak, znana $\mathrm{z}$ narracji personalnej, sytuacja polegająca na chowaniu się narratora za postać. Czytelnik też nie ma wrażenia, jakby poznawał świat zza ramienia jednego z bohaterów opowieści.

36 Ponieważ w pozostałych fragmentach mamy do czynienia z klasyczną fokalizacją (ekstradiegetyczną), proponujemy w przypadku takich tekstów mówić o kategorii „współfokalizacji” jako strategii wzmacniającej zanurzenie. Pozwalałaby ona podkreślić ten wymiar narracji, który Rembowska- 
Niezwykle ważna jest tu również warstwa dźwiękowa - w istocie to nawoływania bohaterów (to, skąd dochodzą) „sterują” wzrokiem czytelnika.

Jednocześnie - mimo przejścia na formułę „ty” (proszący czytelnika o pomoc bohaterowie zwracają się bezpośrednio do niego) - inaczej niż w klasycznej narracji drugoosobowej, czytelnik nie wchodzi tu w rolę jakiegoś tekstowego „ty”, nie musi się z nikim identyfikować, lecz realnie staje się podmiotem działającym w obrębie powieściowego świata. Zatem, ponieważ znika instancja pośrednicząca w przedstawianiu i percypowaniu, opowiadanie nie tyle jest opowiadaniem unaoczniającym, ile - dosłownie - naocznie danym. Czytelnik $W u W u \& C o$ nie wyobraża sobie, co robi jako bohater opowieści, któremu się o nim samym opowiada ${ }^{37}$, lecz - przez chwilę realnie kimś takim jest. I wtedy jego działania, gesty, które wykonuje - zmieniają świat fikcyjny, wpływają na niego (czytelnik np. krzyczy, by obudzić bohaterów, i obudzi ich, ratując im życie, tylko wtedy, kiedy będzie krzyczał wystarczająco głośno). Rozpoczynająca tę opowieść prośba o pomoc, skierowana przez bohaterów wprost do odbiorcy ${ }^{38}$, ustanawia więc specyficzny - oparty na cielesnej współpracy pakt z czytelnikiem.

W postmodernistycznym w charakterze (również przez intertekstualne nawiązania) Maginary zastosowano jeszcze ciekawszy wybieg. Po rozpoczynającym lekturę spersonalizowaniu tekstu (określamy, do kogo należy czytana książka) ${ }^{39}$ zanurzamy się w klasyczną trzecioosobową narrację, której stajemy się bohaterami. Słowem, czytamy o sobie ${ }^{40}$ jako czytelniku - drugim, obok Michaela, któremu trzeba pomóc, głównym bohaterze opowieści. Co więcej, szybko (szybciej nawet niż intradiegetyczni protagoniści) orientujemy się, że nasze realne działania wpływają na rozwój czytanej fabuły. Powieść ta w zupełnie inny sposób przepracowuje i funkcjonalizuje więc opisywane przez Rembowską-Płuciennik jako charakterystyczne dla narracji diadycznej napięcie między własną podmiotowością czytelnika a (jego) zaprojektowanym ,ja” wpisanym w tekst (w wypadku Maginary jako „on”/,ona”, o których

-Płuciennik charakteryzuje za pomocą inspirowanych badaniami kognitywistów kategorii joint action i „współdziałania poznawczego”. M. Rembowska-Płuciennik, O przechodzeniu na ty... oraz eadem, Second-person Narration as a Joint Action, „Language and Literature” 2018, vol. 3. (Roz)grywalny charakter tego tekstu przesądzałby również o możliwości interpretowania go za pomocą takich kategorii, jak „uwspólnienie punktu działania” (punkt działania to kategoria, którą groznawcy chętnie zastępują zapożyczony z klasycznej teorii narracji punkt widzenia). Jednocześnie - ze względu na wykorzystaną w pracy technologię - trudno byłoby automatycznie zastosować w analizie $W u W u \& C o$ filmoznawczą teorię fokalizacji (nadbudowaną zresztą na literaturoznawczej).

37 Por. M. Rembowska-Płuciennik, O przechodzeniu na ty...

38 Nie bez znaczenia jest też to, że nie otrzymuje żadnych wskazówek (tu wybrzmiewa (roz)grywalny charakter tej opowieści). Musi po prostu uważnie wczytać się w tekst i (niczym w grze) wyciaggnąć odpowiednie wnioski, a następnie - realnie działać.

39 Warto podkreślić, że to też gra $\mathrm{z}$ konwencją wielu nowomedialnych tekstów.

40 Dostrzegalna tu intertekstualna gra z powieścią Jeśli zimowa noca podróżny wybrzmiewa w tym tekście wielokrotnie i na wielu poziomach. 
czytamy, w wypadku narracji diadycznej jako wewnątrztekstowe „ty”, z którym ma utożsamić się czytelnik, do którego kierowana jest opowieść). Technologia pozwala powiązać każdy gest czytelnika z rozwojem fabuły, której ostateczny kształt zależy właśnie od naszych działań (podobnie jak w $W u W u \& C o$ realnych, a nie symulowanych czy wyobrażanych). Nierzadko komentowane są one także w narracji (bywa, że bohaterowie denerwują się, iż czytelnik/czytelniczka - tu pada inicjał jego/jej imienia - nieudolnie radzi sobie z zadaniami ${ }^{41}$ ).

Maginary to zatem opowieść, która raczej bezczelnie „wypożycza” nasze ciało do prowadzenia dość klasycznie (bo głównie w słowach) opowiedzianej narracji. Technologia nie tyle służy tu uatrakcyjnieniu książki (choć pod względem estetycznym praca jest niezwykle dopracowana, zaś stosowanie dynamicznej kinetycznej typografii każdorazowo semantycznie i fabularnie uzasadnione), ile właśnie umożliwieniu działania czytelnika wewnątrz opowieści, zaproponowaniu czytelniczego paktu opartego na interesującym nas typie wewnątrztekstowej immersji. Co ciekawe, jest to książka, która oprócz naszego czasu (bo wciąga!) kradnie też... dane z urządzenia, na którym czytamy. Bo skąd książka „wie”, czy czytelnik przeszedł tysiąc kroków (poganiany przez innych bohaterów, którzy w końcu orientują się, że to on ma to zrobić) i czy cała ekipa będzie mogła wsiąść do pociągu? W przywołanej scenie aplikacja (Maginary to również typowe bookapp) korzysta ${ }^{42} \mathrm{z}$ danych krokomierza, podobnie jak $\mathrm{w}$ innych momentach algorytm uwzględnia $\mathrm{w}$ fabule to, czy czytelnik wykonał powierzone mu zadania (np. znalazł źródło zasilania, wytrząsnął żeton z maszyny, odkrył szyfr, zdmuchnął coś itd. ${ }^{43}$ ). Fascynujące w tej powieści jest to, że nie tylko działania czytelnika wpływają na powieściowy świat, lecz i powieściowy świat zwrotnie wpływa potem na jego rzeczywistość. Z jednej bowiem strony (podejmując określone, ucieleśnione działania) targujemy się w powieści o cenę, z drugiej - naprawdę będziemy musieli w AppStore zapłacić tyle, ile wytargujemy (za dostęp do dalszej części opowieści) ${ }^{44}$.

Choć więc powieść Polyakovskiy’ego pozostaje utrzymaną w duchu klasycznych wszechwiedzących narracji opowieścią ujętą w czasem dynamiczne słowa na elektronicznym ekranie, pozwala też na włączenie w mechanizm lektury cielesnej obecności czytelnika, co jest strategią, którą stawiamy w centrum naszych badawczych poszukiwań. Czytelnik nie musi też wchodzić w świadomą interakcję z interfejsem, o jakiej pisze Rembowska-Płuciennik. Działania, jakie podejmuje, znajdują odbicie

41 Jako że jest to opowieść (roz)grywalna, presja czasu, odmierzanego rządzącym się dziwnymi prawami zegarem umieszczonym na dole każdej strony, udziela się wszystkim.

42 Za naszą zgodą... Ale jak tu się nie zgodzić, gdy inaczej nie da się poznać opowieści?

43 Wymienione jako przykładowe akcje obrazują różnorodność „wymaganych” działań czytelnika: od prostego podłączania czytnika do zasilania (choć zadanie nie zostało sformułowane wprost), przez fizyczne aktywności (chodzenie, kręcenie się w kółko, potrząsanie czytnikiem), aż po takie działanie, jak dmuchanie czy szeptanie.

44 Tylko początek Maginary jest bezpłatny. 
w fabule i nie mają nic wspólnego z ,obsługą sprzętu i oprogramowania”"45, „wykonywaniem konkretnych operacji na klawiaturze/ekranie/interfejsie"46.

Żaden z przywołanych tekstów nie będzie tu przedmiotem pogłębionych analiz, przywołujemy je, by zasygnalizować, jak e-literatura może eksplorować interesujące nas przestrzenie haptyczności ${ }^{47}$. W dalszej części tego szkicu na przykładzie Pry (narracji pozwalającej czytelnikom (?) poczuć wspomnienia pod palcami) ${ }^{48}$ pokażemy, jak dalece skomplikowane mogą być sposoby haptycznego angażowania czytelnika ${ }^{49}$. Doskonałą codą do naszych rozważań jest zamieszczony w dziale Omówienia i rozbiory szkic poświęcony Queerskins: A Love Story - doświadczeniu VR bazującemu na pełnym cielesnym wejściu w świat opowieści - czytanemu w kontekście pamięci (współ)doświadczanej i (współ)tworzonej.

\section{Pamięć pod palcami - dotyk i percepcja haptyczna w ucieleśnionym doświadczeniu pamięci (roz)grywalnej}

Utworowi Pry Samanthy Gorman i Danny’ego Cannizzaro poświęcono dotąd wiele uwagi $^{50}$, postanowiłyśmy jednak przywołać ponownie ten wielokrotnie nagradzany i analizowany tekst i potraktować go tym razem jako przyczynek do refleksji nad sposobami wykorzystania potencjału percepcji haptycznej, dotyku i gestu w immersyjnym doświadczeniu pamięci (roz)grywalnej. Wprowadzanego tu pojęcia pamięci (roz)grywalnej ${ }^{51}$ nie wiążemy wyłącznie z tytułami gier wideo, w któ-

45 M. Rembowska-Płuciennik, Po(d)taczeni..., s. 271.

46 Ibidem.

47 Ten obszar badań (w który wpisuje się wiele z prezentowanych w tym numerze analiz) Rembowska-Płuciennik nazwała „narratologią bezpośredniej obecności”. M. Rembowska-Płuciennik, O przechodzeniu na ty ..., s. 262. Badaczka dookreśla ją jako „,narratologiczne studia nad współczesnymi mediami stymulującymi dostęp do fizykalności doświadczenia" (ibidem).

Doświadczenie lektury poszerzone jest tu o elementy haptycznej interakcji z tekstem.

49 Charakteryzowane przez nas strategie warto byłoby może szerzej rozpatrzeć w kontekście narracyjnych modeli intersubiektywności, zastanowić się nad włączeniem do formułowanego przez Rembowską-Płuciennik na łamach książki Poetyka intersubiektywności. Kognitywistyczna teoria narracji a proza XX wieku (Toruń 2012) repertuaru figur intersubiektywności i takich, które określiłybyśmy jako haptyczne (byłyby charakterystyczne raczej dla wieku XXI). Rozważania te znacząco przekraczają jednak ramy tego szkicu.

50 Zob. A. Przybyszewska, Więcej niż książka, więcej niż film, więcej niż gra. O czytaniu (?) „PRY”, „Sztuka Edycji” 2016, nr 10(2), s. 103-114; M. Górska-Olesińska, M. Pisarski, The Return of Stretchtext: From Obscurity to Omnipresence, w: Literární a knižní kultura v digitálním věku, ed. L. Pořízková, M. Navrátilová, Vydala Univerzita Palackého w Olomouci, Olomouc 2015, s. 89-98; D. Johnston (Jhave), Prying: Jhave on the Tender Claws' New App, https://lareviewofbooks.org/ article/prying-jhave-on-tender-claws-new-app/ (dostęp: 20.04.2020).

51 Próbę definicji pojęcia playable memory podejmowała Monika Górska-Olesińska w wystapieniu konferencyjnym Tapping the Mind: Memories Beneath Your Fingers podczas konferencji Electronic Literature Organization Conference and Festival „Mind the Gap” (Montreal, 14.08.2018). 
rych wytwarzanie współdzielonej pamięci narracyjnej gracza i gracza-bohatera (shareable memory of player and player character) stanowi cel gry i strukturyzuje rozgrywkę ${ }^{52}$. Zamiast tego proponujemy, by objać nim szerokie spektrum dzieł-instrumentów, które mobilizują odbiorców do interakcji z medialnymi figuracjami pamięci/modelami zmediatyzowanej pamięci, a jednocześnie do gier z pamięcią własną. Na jednym biegunie tego spektrum sytuujemy prace artystyczne wykorzystujące mechanizmy asocjacji i bifurkacyjny potencjał hiperlinków, włączające odbiorcę w podróż po elektronicznych archiwach wspomnień (jak Immemory Chrisa Markera [1997]) $)^{53}$, na drugim zaś biegunie - komercyjne gry wideo, które oferują doświadczanie mechanizmów działania pamięci $\mathrm{w}$ formie gameplayu ${ }^{54}$. Między nimi lokujemy e-literackie interaktywne memoir (takie jak $i$ - in the white darkness Reinera Strassera i M.D. Coverley [2004]), a także projekty artystyczne, które dzięki narzędziom VR i AR zanurzają cieleśnie odbiorcę zarówno we wspomnieniach fikcyjnych i półfikcjonalnych bohaterów (Queerskins: A Love Story Illyi Szilak i Cyrila Tsiboulskiego [2018]), jak i w osobistej pamięci realnie istniejących osób (Vestige [2018] i Fragments [2020] Aarona Bradbury'ego). Tu też znajduje swe miejsce Pry - medialna hybryda, „więcej niż książka, więcej niż film, więcej niż gra" ${ }^{55}$.

Tym, co czyni Pry utworem wyjątkowym na tle innych aplikacji, stworzonych z myślą o urządzeniach wyposażonych w ekrany dotykowe, jest sposób, w jaki gesty dłoni, warunkujące interakcję z interfejsem dzieła, wprzęgnięte zostały w kognitywny proces, w którym odbiorca rekonfiguruje i odgrywa (enact) pamięć głównego bohatera $^{56}$. Mowa o gestach, a właściwie eksperymentalnych figurach gestycznej

52 Koncepcję współdzielonej/współużywanej pamięci narracyjnej gracza i gracza-bohatera rozwija David Ciccoricco. Zob. D. Ciccoricco, Refiguring Minds in Narrative Media, University of Nebraska Press, Lincoln 2015, s. 148.

53 Twórczość Chrisa Markera na gruncie polskim wnikliwie analizowali Barbara Kita i Andrzej Pitrus. Zob. B. Kita, Refleksje o fotografii.., s. 15-29; eadem, Pejzaże w mediach Chrisa Markera, „Studia de Cultura" 2017, nr 9(4), s. 78-85; A. Pitrus, Fundament pamięci - o „fotograficznej powieści” Chrisa Markera, „Kwartalnik Filmowy” 2006, nr 54-55, s. 231-236.

54 David Ciccoricco w charakterze egzemplifikacji pamięci doświadczanych jako gameplay przywołuje komercyjne tytuły - grę Heavy Rain (2010) Quantic Dream i grę Remember Me (2013) Dontnod Entertainment.

55 A. Przybyszewska, Więcej niż książka... Analizę utworu Pry prezentowała także Kathi Inman Berens podczas konferencji Digital Humanities 2015, określając ją mianem grywalnej książki na iPad (playable book for iPad). Zob. K.I. Berens, Novel Games. Playable Books for iPad, wpis opublikowany 14.06.2016, http://kathiiberens.com/2016/07/14/playable-books-dh2016/ (dostęp: 20.04.2020).

56 David Ciccoricco pisze: „Wyobrażenie/figura wkradania się w/wsuwania się pomiędzy myśli głównego bohatera jest wiodącą metaforą narracji. O ile w pewnym sensie można stwierdzić, że każda fikcja narracyjna jest w istocie ćwiczeniem się w otwieraniu/rozwieraniu umysłów innych i zaglądaniem do ich wnętrza, to w przypadku Pry metafora ta w sposób płynny zintegrowana została z semantyką interfejsu w sposób, który bez wątpienia odróżnia ją nie tylko od psychologicznie ukierunkowanych narracji pisanych z myślą o medium drukowanej książki, ale czyni wyjątkową 
manipulacji (figures of manipulation) $)^{57}$, które polegają na „szczypaniu” ekranu (pinch and hold) oraz rozsuwaniu dwóch palców i pozostawianiu ich w rozwarciu w stałym kontakcie z powierzchnią wyświetlacza (spread and hold). Wykorzystane instrumentalnie, służą one mechanicznej eksploracji stretchtekstowej struktury Pry ${ }^{58}$, a jednocześnie - w momentach, gdy w sposób skeumorficzny naśladują ruch rozchylania i zamykania powiek - stają się instrumentami odsłaniania fabuły, zanurzając odbiorcę naprzemiennie to w wypełnionej flashbackami i innymi okruchami pamięci podświadomości ślepnącego, cierpiącego na PTSD głównego bohatera (pinch and hold), to znów w ukazywanej z perspektywy pierwszej osoby (POV) otaczającej go rzeczywistości (spread and hold).

Zaprojektowane przez Gorman i Cannizzaro figury gestycznej manipulacji pinch and hold oraz spread and hold, będące subwersywnymi przetworzeniami znormalizowanych i powiązanych ze sobą gestów spread i stretch, których konwencjonalne zastosowanie sprowadza się do powiększania i zmniejszania zawartości ekranu, w nowej odsłonie - co podkreśla Astrid Ensslin - „służą odgrywaniu (enact) złożonych psychologicznych i fizjologicznych procesów powiązanych z syndromem stresu pourazowego i stopniową utratą wzroku" 59 .

Sens instrukcji, która wprowadza widza w mechanizm lektury (Pry open a troubled mind and hold its thoughts in your hands / Wdzieraj się w niespokojny umysł Jamesa i chwytaj w ręce jego myślii ${ }^{60}$, uchwycić można jedynie w relacji z dwoma frazeologizmami: pry open (,podważać”, „wyważać”) i pry into („wtrącać się”, „wściubiać nos”). Znaczenie tytułowego Pry rodzi się bowiem „pomiędzy” rzeczywistym fizycznym działaniem (otwieraniem, rozsuwaniem czegoś z użyciem siły) i metaforą odsyłającą do sytuacji wtargnięcia (intrusion) w prywatność innej osoby.

Jednocześnie w sformułowanych przez Gorman i Cannizzaro „wskazówkach lekturowych" (Spread and hold open to see through James eyes / Pinch and hold close to enter James subconscious) zawarte zostało implicytnie zaproszenie do

także na tle wszystkiego, co do tej pory stworzono w polu literatury elektronicznej”. D. Ciccoricco, Rebooting Cognition in Electronic Literature, w: Bloomsbury Handbook of Electronic Literature, ed. J. Tabbi, BloomsburyPublishing, London 2019, s. 159.

57 Powołujemy się tu na wystapienie konferencyjne Astrid Ensslin Mind the Tap: Towards a Ludosemiotics of Mobile E-literature, wygłoszone podczas konferencji Electronic Literature Organization Conference and Festival „Mind the Gap” (Montreal, 14.08.2018).

58 O stretchtekście pisał Mariusz Pisarski. Zob. Xanadu. Hipertekstowe przestrzenie prozy, Korporacja Ha!art, Kraków 2013, s. 249.

59 A. Ensslin, op. cit.

60 Przywoływane tu ,zaproszenia do lektury” towarzyszyły pierwotnie prezentacji aplikacji w systemie dystrybucji AppStore, jednak tekst prezentacji zmieniono wraz z kolejnymi aktualizacjami aplikacji. Został on jednak przez nas udokumentowany w formie zrzutów ekranowych, a także jest cytowany w tekstach innych badaczy. Zob. M. Mencia, Creative Process: Interweaving Methods, Content and Technology, w: Digital Media and Textuality. From Creation to Archiving, ed. D. Côrtes Maduro, Transcript Verlag, Bielefeld 2017, s. 143. 
„współdziałania poznawczego"61, ustanawiające specyficzny pakt z czytelnikiem-widzem-graczem, oparty na założeniu, że jego gesty pozostawać będą odtąd w ścisłej relacji z percepcją bohatera. Owo współdzielenie już nie tyle punktu widzenia, co właśnie aparatu percepcyjnego (wcześniej nazywane przez nas „współfokalizacją) uchwycili David Ciccoricco i David Large, omawiając sekwencje początkowe pierwszego rozdziału Pry:

Rozdział pierwszy (Below and Above) otwiera podtytuł Sześć lat później, na który nakłada się taktylna pamięć opadającej fotografii z polaroidu przedstawiającej zielonooką kobietę. [...] Następne ujęcie ukazuje Jamesa leżącego w łóżku z tzw. perspektywy wysokiej - kamera ulokowana pod sufitem zwrócona jest w dół, a my, wraz z zoomem, trafiamy wprost w rozszerzoną źrenicę prawego oka Jamesa, którego powieki zamykają się nagle wokół nas - ta wizualna metafora implikuje, że odtąd pochłonięci jesteśmy przez jego perspektywę [we are engulfed by his perspective]. Odkrywamy, dzięki myślom rozbłyskującym na ekranie w trybie błyskawicznej wizualnej prezentacji informacji (RSVP), że jest on ,przebudzony, jednak nie w pełni”. Podobnie jak i my. Otrzymujemy polecenie, by „rozsuwać” pozostające w kontakcie $\mathrm{z}$ ekranem palce w celu spoglądania oczami Jamesa; gdy wykonamy po raz pierwszy to zadanie, zarówno my, jak i on otrzymujemy informację o naszej kondycji: „Tak, nie mogę się poruszyć"

Wydobywaniu z podświadomości Jamesa strzępków wspomnień, podawanych w formie tekstów, dźwięków, ruchomych i nieruchomych obrazów, oraz próbom „uchwycenia w palce” / „przytrzymania pod palcami” przebłysków pamięci, na które odbiorca trafia, zanurzając się w niespokojny umysł głównego bohatera, towarzyszy nieusuwalne napięcie. Można zaryzykować stwierdzenie, że w doświadczeniu odbiorczym Pry splatają się chiazmatycznie dwa doświadczenia, sytuujące się zazwyczaj na przeciwstawnych biegunach: z jednej strony sprawczość gestycznego działania nacechowanego przemoca, budzącego skojarzenia z performansem Pryings (1971) i obrazami Vito Acconciego, otwierającego na siłę oczy swojej partnerki, z drugiej zaś doświadczenie bycia ofiarą przemocy, nie tyle fizycznej, ile oddziałującej na system nerwowy „przemocy wrażenia”63, której figurą mogłaby stać się młoda kobieta z prologu Psa andaluzyjskiego, biernie poddająca się zabiegowi rozchylania powiek, zmuszona do percepcji „nie-do-zniesienia obrazów”64. Napięciem tym naznaczony jest odbiór końcowych scen rozdziału Below and Above - sięga ono zenitu w momencie, w którym do oczu Jamesa zbliża się ostrze pochwyconego przez Jessie noża, a gestyczna figura „szczypania” ekranu, otwierająca drogę ucieczki

61 M. Rembowska-Płuciennik, O przechodzeniu na ty..., s. 260.

62 D. Ciccoricco, D. Large, Caution: Simulation Ahead: Complexity and Digital Narrativity, w: Narrative Complexity: Cognition, Embodiment, Evolution, eds. M. Grishakova, M. Poulaki, University of Nebraska Press, Lincoln 2019, s. 60.

63 Por. J. Spalińska-Mazur, Śmierć oka. Gest przemocy w filmie Luisa Buñuela i Salvadora Dali „Pies andaluzyjski”, w: Stowo i gest, red. ks. H.J. Sobeczko, Z.W. Solski, Wydawnictwo i Drukarnia Św. Krzyża, Opole 2009, s. 324. 
w podświadomość, traci nagle swą funkcjonalnośćc5. Oko odbiorcy atakowane jest też w sposób bardziej dosłowny, gdy zamykając powieki Jamesa, wnikając w jego podświadomość, naraża on własny nerw wzrokowy na atak stroboskopowego montażu flashbacków.

Słowa rozbłyskujące niczym światło stroboskopu hipnotyzują umysł, ogniskując na sobie jego uwagę; sytuują przy tym odbiorcę w pozycji psychoanalitycznego chirurga, emocjonalnego archeologa, odgrzebującego zdarzenia pogrzebane w okolicznościach przypominających sejsmiczną katastrofę. Powieści zachęcają odbiorców do „empatycznego” voyeuryzmu, Pry jest natomiast wymuszoną spowiedzią (forced confessional), przestrzenią, w której tekst odsłania więcej, niż ma zamiar, i pęka, gdy jest dotykany $[\ldots]^{66}$.

Zastosowana w sekwencjach flashbacków technika RSVP jest idealną formą prezentacji treści podświadomych - strzępków myśli i obrazów, „wewnętrznych refrenów i litanii, głosów psychiki, [...] traum, które pozostają w uśpieniu, dopóki się ich nie dotknie" ${ }^{67}$, jednak intensywne bodźce wizualne towarzyszące flashbackom, gwałtowne przejścia między bielą i czernią, ostrymi i rozmytymi obrazami, są trudne do zniesienia dla oczu odbiorcy, który zaczyna odczuwać boleśnie, ,że oko nie tylko widzi, ale i »czuje«, że jest częścią ciała jak pozostałe [organy] [...], że może się fizycznie zmęczyć" ${ }^{68}$.

Poczynione do tej pory spostrzeżenia w oczywisty sposób odsyłają do tych kontekstów interpretacyjnych, które wiążą się z teoriami taktylności obrazów, haptycznej wizualności czy taktylnego widzenia. My chciałyśmy natomiast zwrócić uwagę także na to, że nie tylko mięśnie oka ulegają nadwyrężeniu, gdy odbiorca zanurza się w myśli i wspomnienia Jamesa - instrument do gier z pamięcią, jakim jest Pry, skonstruowano tak, iż ponad miarę eksploatuje on mięśnie palców, mięśnie środkowe dłoni i nadgarstka (szczególnie w przypadku tych nastawionych na rezultat widzów-czytelników-graczy, którzy motywowani systemem nagród, zamykają się w pętli lektury $\left.{ }^{69}\right)$. Operowanie Pry wymaga „nietrywialnego wysiłku”, nie tylko w wymiarze kognitywnym, ale też w zakresie manipulacji gestycznej: po pierwsze, w obrębie poszczególnych rozdziałów zmieniają się figury gestyczne oraz ich funkcje (ponieważ instrukcja interakcji towarzyszy jedynie pierwszemu rozdziało-

65 Prolog Psa andaluzyjskiego przywołuje w swej interpretacji Pry Stephanie Strickland. Zob. S. Strickland, The Death and Re-Distribution of V, w: \#WomenTechLit, ed. M. Mencia, West Virginia University Press, Morgantown 2017, s. 417-426.

D. Johnston (Jhave), op. cit.

67 Ibidem.

${ }_{68}$ Intencjonalnie zestawiamy tutaj sekwencje flashbacków Jamesa z przywoływanymi przez Kubę Mikurdę w tekście Touching Images. Proszę dotykać eksperymentami filmowymi found footage Contre-jour Christophe'a Girardeta i Matthiasa Müllera (2009) oraz Instructions for Light \& Sound Machine Petera Tscherkassky'ego (2005). Zob. K. Mikurda, Touching Images. Proszę dotykać, „Widok. Teorie i Praktyki Kultury Wizualnej” 2015, nr 12, s. 9, http://pismowidok.org/index.php/ one/article/view/307/683 (dostęp: 20.04.2020). 
wi, kolejne figury gestyczne, umożliwiające dalsze eksplorowanie pamięci Jamesa, odbiorca musi odkryć samodzielnie). Po drugie, interakcję zaprojektowano tak, że palce czytelnika muszą pozostawać w niemal nieustającym kontakcie z powierzchnią ekranu iPada; dłoń nie odpoczywa ani przez chwilę, a jej postępujące zmęczenie skutkuje zyskującym na intensywności wrażeniem, że w rozsuwanie „zwiniętej w harmonijkę" struktury pamięci Jamesa wkładać należy coraz więcej wysiłku, jakby materia jego wspomnień tężała, stawiając coraz większy opór. „Nasze doświadczenie Pry balansuje na krawędzi frustracji” - zauważają David Ciccoricco i David Large:

Utrzymywanie oczu Jamesa w pozycji otwartej wymaga fizycznego wysiłku, zachowania stałego kąta rozwarcia pomiędzy kciukiem a palcem wskazującym w oczekiwaniu na rozwój lub rozwiązanie akcji; ścięgna mięśni odpowiadających za zginanie palców są nieustannie napięte, gdy odbiorca stara się utrzymać kontakt z oleofobową powłoką ekranu dotykowego. Z pewnością nie jest to sposób, w jaki zazwyczaj „konsumujemy narrację"

Dysponując jedynie kilkoma akapitami, trudno poddać analizie wszystkie figury gestyczne Pry, my skupiłyśmy się tu ledwie na jednej, problematyzując ją dodatkowo w kontekście indywidualnego doświadczenia odbioru ${ }^{71}$ - naszym celem było jednak pokazanie, że „wypożyczaniu” ciała na potrzeby działania immersyjnej maszyny tekstu może towarzyszyć także poczucie cielesnego dyskomfortu. Taki dyskomfort (także połączony z napędzającą doświadczenie przyjemnością z grania) towarzyszył również nie tylko wykonującemu gesty, ale i zanurzającemu się całym ciałem w tekst odbiorcy kanonicznego już projektu Screen, który „wypożyczał” ciało czytelnika na potrzeby opowieści $\mathrm{w} \mathrm{VR}^{72}$.

Przywołując tę pracę, otwieramy pole do, znacznie przekraczającej ramy tego szkicu, dyskusji o haptycznej poetyce odbioru (około)literackich dzieł, w które możemy zanurzyć się całym ciałem. Jednym z przykładów jest projekt Home/Mother/ Heaven Caitlin Fisher i Tony'ego Vieiry, w którym dzięki technologii AR miejsce $i$,zamieszkujące” je przedmioty same opowiadają swoją historię. Analiz tej pracy szczególnie zabrakło nam w tym numerze, podobnie jak rozważań o Circle (innej korzystającej z technologii AR pracy autorki, której odbiorca - „,czytając” ukryte w walizeczce przedmioty - odsłania wspomnienia trzech generacji kobiet). Innym przykładem byłaby stworzona w technologii VR praca Queerskins: A Love Story, której analizę czytelnik znajdzie w dziale Omówienia i rozbiory ${ }^{73}$.

70 D. Ciccoricco, D. Large, Caution: Simulation ..., s. 61-62.

71 Doświadczenie dzieła e-literackiego może mieć także charakter wspólnotowy. Zob. M. Górska-Olesińska, Pamięć (wspól)tworzona $i$ (współ)doświadczana - partycypacyjne i cielesne wymiary doświadczenia VR (, Queerskins: A Love Story” Illyi Szilak i Cyrila Tsiboulskiego) [w tym numerze].

72 Wśród wielu omówień tej pracy kontekst pamięci (roz)grywalnej najmocniej podkreślony jest w analizach M. Górskiej-Olesińskiej. Zob. eadem, Tekstowe instrumenty do gier z pamięcia, „,Kultura Popularna" 2010, nr 3-4 (29-30), s. 31-35.

73 Zob. eadem, Pamięć (wspót)tworzona i (wspól)doświadczana-partycypacyjne i cielesne wymiary doświadczenia VR (,, Queerskins: A Love Story”’ Illyi Szilak i Cyrila Tsiboulskiego) [w tym numerze]. 
By domknąć nasze rozważania i powrócić do transmedialnej perspektywy, warto na koniec przywołać jeszcze tzw. physical narratives grupy Time's Up (ich Turnton Docklands jest tekstem przewrotnie grającym z immersyjnym zanurzaniem w przestrzenie pamięci - proponuje wycieczkę w zmaterializowany antyutopijny świat z przyszłości, by opowiadać o jego przeszłości ${ }^{74}$ ). Prace te, przybierające formy materialnych eksplorowalnych immersyjnych przestrzeni i dające się określić jako VR bez VR, ,wypożyczają" ciała odbiorców po to, by poznawali te światy - dosłownie wchodząc w nie. Sami artyści podsumowują:

W PN [physical narratives - przyp. M.G.-O., A.P.], w myśl porzekadła „Słyszę i zapominam, widzę i pamiętam, robię i rozumiem" (I hear and I forget, I see and I remember, I do and I understand), zwiedzający (visitors) mogą odnosić się do abstrakcyjnych pojęć jako zjawisk empirycznych, co czyni je bardziej dostępnymi i łatwiejszymi do zrozumienia. Zamiast czytać i analizować lub oglądać i wchłaniać, zamieszkują oni scenariusz, ucząc się poprzez działanie ${ }^{75}$.

Szczerze wierzymy, że otwarta przez nas dyskusja spotka się z odzewem, choć aktualna sytuacja wystawia na próbę sztukę potrzebującą „wypożyczać” ciała odbiorców (o czym więcej w COVID-CODZIE w dziale Omówienia i rozbiory).

$* * *$

Autorzy artykułów opublikowanych w oddawanym w ręce czytelnika numerze „Przeglądu Kulturoznawczego" przyglądają się immersyjnym przestrzeniom pamięci z różnych perspektyw i definiują je na wiele sposobów.

Agnieszka Przybyszewska w tekście $W$ stronę lokacyjnego monologu wypowiedzianego. O eksplorowaniu literackich ucieleśnionych przestrzeni pamięci konsekwentnie kontynuuje namysł nad interesującą nas problematyką „wypożyczania” ciał odbiorców. Analizując instalację Data Urns Daniela Hubera oraz audio-walk Her Long Black Hair Janet Cardiff, dokonuje reinterpretacji tradycyjnych teoretycznoliterackich kategorii, by prawidłowo uchwycić ucieleśnione doświadczenie tekstów o „dominującym komponencie werbalnym”.

Również Ewa Wójtowicz obejmuje refleksją obszar sztuki (nowo)medialnej. W artykule Pałac (rozszerzonej medialnie) pamięci. „Atmospheric Memory” Rafaela Lozano-Hemmera analizuje twórczość wybitnego meksykańskiego artysty w szer-

74 Jednocześnie, choć nie odważyłybyśmy się twierdzić, że jest to tekst literacki (bo jest ewidentnie postmedialny i sytuujący się ponad wszelkimi podziałami), literacki, a zwłaszcza werbocentryczny komponent jest w nim niezwykle istotny. W tej współczesnej, niby nowomedialnej, ale jednak analogowej, „sylwie ponowoczesnej” czy (niewyłącznie) „tekstowej hybrydzie” (sądzimy, że w analizach tego tekstu można by odświeżyć te koncepty teoretycznoliterackie) sama opowieść, która ma prowokować odbiorców do podjęcia refleksji i działań (projekt ten wpisuje się też w obszar teatru partycypacyjnego), dzieje się w słowach: w tekstach mówionych (kilkaset minut nagrań dialogów niby-obecnych postaci) i pisanych (drukowana gazeta z przyszłości, ulotki, plakaty). Bez nich, podobnie jak bez „wypożyczonego” ciała ich czytelnika - instalacja nie miałaby szansy wybrzmieć, a właściwie w ogóle „zadziałać”, być zrozumiana.

75 M. Kuzmanovic, T. Auer, N. Gaffney, T. Boykett, Making Things Physical, „Journal of Futures Studies” 2019, nr 23(4), s. 108 [podkreślenia - M.G.-O., A.P.]. 
szym kontekście historycznym, zestawiając jego prace z innymi dziełami lokującymi doświadczenie pamięci w rzeczywistości rozszerzonej - Frozen Palaces Forced Entertainment Group, Memory Theater VR Agnes Hegedüs i Extramission 6 (Black Maria) Lindsay Seers. Zwraca przy tym szczególną uwagę na architektoniczny „komponent” przywoływanych projektów i rekonceptualizuje - a raczej medialnie rozszerza - samą metaforę pałacu pamięci.

Agnieszka Jelewska jest kolejną autorką, która buduje swe rozważania wokół dzieła sztuki. Badaczka poświęca tekst Postcolonial Sensations. Remote Sensing Technologies and the Geological Approach in Art and Science nagrodzonemu na Festiwalu Ars Electronica w 2018 roku projektowi Tropics francuskiej artystki Mathilde Lavenne, która posłużyła się technologią skaningu lidar, by zwizualizować historie i wspomnienia będących potomkami francuskich kolonizatorów mieszkańców meksykańskiego miasta Jicaltepec. Jelewska, analizując Tropics w szerszym kontekście geoantropologii, przygląda się także samej technologii, pytając o relacje między technokulturą, naturą, pamięcią i nakładającymi się na nie: kolonialną logiką produkcji wiedzy i mikropolitykami regulowania afektów.

Tekst Pawła Grabarczyka The Past through Stereoscopic Lenses. Video Games Nostalgia in Virtual Reality kieruje z kolei uwagę widza ku dyspozytywowi VR, przynosząc ze sobą cztery interesujące studia przypadku ucieleśnionego doświadczenia gier retro $\mathrm{w}$ przestrzeni rzeczywistości wirtualnej.

Krytyczny namysł nad technologią VR proponują Agnieszka Dytman-Stasieńko i Jan Stasieńko. W artykule „Odmienne przestrzenie uzdrawiania” - psychologiczne terapie VR w perspektywie krytycznych i definicyjnych aspektów pojęcia rzeczywistości wirtualnej badacze omawiają terapeutyczne zastosowania technologii rzeczywistości wirtualnej, wskazując przy tym na ich „często polityczny” i ideowy charakter, a równocześnie sygnalizują możliwość uznania rzeczywistości wirtualnej za swoiste „medium pamięci”.

Z kolei Blanka Brzozowska w artykule Laban Bartenieff Movement System jako inspiracja dla ucieleśnionego designu w kontekście projektowania przestrzeni miejskiej podejmuje ważny, a jednocześnie, co podkreśla autorka, „wciąż nierozwiązany problem artykulacji doświadczenia somatycznego" w procesie projektowym. Rozważania badaczki, wskazującej na możliwość wykorzystania w kontekście praktyk ucieleśnionego designu ,języka ruchu” opracowanego w ramach systemu LBMS (Laban Bartenieff Movement System), nabierają szczególnego znaczenia wobec obserwowanej w projektowaniu doświadczeń VR tendencji do eksploatowania kontekstów związanych z koncepcjami empatii kinestetycznej.

Numer zamykają omówienia: Pamięć (wspót)tworzona i (wspót)doświadczana partycypacyjne i cielesne wymiary doświadczenia VR (,Queerskins: A Love Story” Illyi Szilak i Cyrila Tsiboulskiego) Moniki Górskiej-Olesińskiej - tekst poświęcony jednej z ciekawszych „,immersyjnych przestrzeni pamięci”, jakie powstały w obszarze e-literatury, artykuł Zmienna trwałość dzieła - problem pamięci sztuki mediów w kontekście wystawy „Reinkarnacja sztuki mediów” autorstwa Sylwii Szykownej, 
tekst Pawła Korzeba Epigenetic Paradigm of Critical Rationality in "Before Tomorrow” by Catherine Malabou oraz zapowiadany już tekst COVID-CODA. Zakaz ,wypożyczania ciat”, czyli o immersyjności pandemicznej i tęsknotach za „prawdziwymi symulakrami” Agnieszki Przybyszewskiej.

\section{Bibliografia}

Berens K.I., Novel Games. Playable Books for iPad, 14.06.2016, http://kathiiberens. com/2016/07/14/playable-books-dh2016/ (dostęp: 20.04.2020).

Borsuk A., The Book, The MIT Press, Cambridge-London 2018.

Bouchardon S., Figures of Gestural Manipulation in Digital Fictions, w: Analyzing Digital Fiction, eds. A. Bell, A. Ensslin, H.K. Rustad, Routledge, New York 2014.

Bouchardon S., Mind the Gap! 10 Gaps for Digital Literature?, „Electronic Book Review” 2019, May 5, http://electronicbookreview.com/essay/mind-the-gap-10-gaps-for-digital-literature/ (dostęp: 1.06.2019).

Chetcuti C., Review: Samantha Gorman, Danny Cannizzaro PRY, „CounterText” 2016, 2.2, s. 256-267.

Ciccoricco D., Rebooting Cognition in Electronic Literature, w: Bloomsbury Handbook of Electronic Literature, ed. J. Tabbi, Bloomsbury Publishing, London 2019, s. 151-163.

Ciccoricco D., Refiguring Minds in Narrative Media, University of Nebraska Press, Lincoln 2015.

Ciccoricco D., Large D., Caution: Simulation Ahead: Complexity and Digital Narrativity, w: Narrative Complexity: Cognition, Embodiment, Evolution, eds. M. Grishakova, M. Poulaki, University of Nebraska Press, Lincoln 2019, s. 56-72.

Coover R., Pry as a Cinematic Novel: A Conversation with Samantha Gorman, w: The Digital Imaginary: Literature and Cinema of the Database, ed. R. Coover, Bloomsbury Publishing, London 2019, s. 61-73.

Digital Media and Textuality: From Creation to Archiving, ed. D. Côrtes Maduro, Transcript Verlag, Bielefeld 2017.

Ensslin A., Mind the Tap: Towards a Ludosemiotics of Mobile E-literature, wystapienie wygłoszone podczas konferencji Electronic Literature Organization Conference and Festival „Mind the Gap” (Montreal, 14.08.2018).

Górska-Olesińska M., Tapping the Mind: Memories Beneath Your Fingers, wystapienie wygłoszone podczas konferencji Electronic Literature Organization Conference and Festival „Mind the Gap” (Montreal, 14.08.2018).

Górska-Olesińska M., Tekstowe instrumenty do gier z pamięcia, ,Kultura Popularna” 2010, nr 3-4 (29-30), s. 28-35.

Górska-Olesińska M., Pisarski M., The Return of Stretchtext: From Obscurity to Omnipresence, w: Literární a knižni kultura v digitálním věku, eds. L. Pořízková, M. Navrátilová, Vydala Univerzita Palackého w Olomouci, Olomouc 2015, s. 89-98.

Johnston (Jhave) D., Prying: Jhave on the Tender Claws'New App, https://lareviewofbooks. org/article/prying-jhave-on-tender-claws-new-app/ (dostęp: 20.04.2020).

Kita B., Immemory (1997) Chris Marker, w: Klasyczne dzieła sztuki nowych mediów, red. P. Zawojski, Instytucja Kultury Katowice - Miasto Ogrodów, Katowice 2015, s. 105-110.

Kita B., Między przestrzeniami. O kulturze nowych mediów, Rabid, Kraków 2003. 
Kita B., Pejzaże w mediach Chrisa Markera, „Studia de Cultura” 2017, nr 9(4), s. 78-85.

Kita B., Refleksje o fotografii w twórczości Chrisa Markera, „Przegląd Kulturoznawczy” 2019, nr 1(39), s. 15-29.

Kuzmanovic M., Auer T., Gaffney N., Boykett T., Making Things Physical, „Journal of Futures Studies" 2019, nr 23(4).

Lupton C., Chris Marker: Memories of the Future, Reaktion Books, London 2005.

Machon J., Immersive Theatres: Intimacy and Immediacy in Contemporary Performance, Palgrave Macmillan, London 2013.

Marker Ch., Immemory by Chris Marker, 2011, https://chrismarker.org/chris-marker/immemory-by-chris-marker/ (dostęp: 20.04.2020).

Mencia M., Creative Process: Interweaving Methods, Content and Technology, w: Digital Media and Textuality: From CReation to Archiving, ed. D. Côrtes Maduro, Transcript Verlag, Bielefeld 2017, s. 133-150.

Mikurda K., Touching Images. Prosze dotykać, „Widok. Teorie i Praktyki Kultury Wizualnej" 2015, nr 12, http://pismowidok.org/index.php/one/article/view/307/683 (dostęp: 20.04.2020).

Milk Ch., How Virtual Reality Can Create the Ultimate Empathy Machine, TED Talk, March 2015, https://www.ted.com/talks/chris_milk_how_virtual_reality_can_create_the_ultimate_empathy_machine (dostęp: 20.04.2020).

Modi memorandi. Leksykon pamięci kultury, red. M. Saryusz-Wolska, R. Traba, Wydawnictwo Naukowe Scholar, Warszawa 2014.

Pisarski M., Xanadu. Hipertekstowe przemiany prozy, Korporacja Ha!art, Kraków 2013.

Pitrus A., Fundament pamięci - o „,fotograficznej powieści” Chrisa Markera, „Kwartalnik Filmowy" 2006, nr 54-55, s. 231-236.

Przybyszewska A., Literacka immersja i technologia step-in-book, czyli o przenikaniu sie światów literackich i rzeczywistych, w: Nowoczesne technologie czy tradycyjne metody? O tendencjach $w$ krzewieniu kultury czytelniczej młodego pokolenia, red. M. Antczak, A. Walczak-Niewiadomska, WUŁ-SBP, Łódź-Warszawa 2017.

Przybyszewska A., Po(d)żeranie tekstu. Wstęp do rozważań o czytaniu kinetycznym, w: e-polonistyka 3, red. A. Dziak, A. Kopacz, Wydawnictwo KUL, Lublin 2016.

Przybyszewska A., Więcej niż książka, więcej niż film, więcej niż gra. O czytaniu (?) „PRY”, „Sztuka Edycji” 2016, nr 10(2), s. 103-114.

Rembowska-Płuciennik M., O przechodzeniu na ty... Narracja diadyczna wśród literackich reprezentacji świadomości bohatera, w: $(W)$ sieci modernizmu. Historia literatury - poetyka - krytyka. Prace ofiarowane Włodzimierzowi Boleckiemu, red. A. Kluba, M. Rembowska-Płuciennik, Instytut Badań Literackich PAN, Warszawa 2017.

Rembowska-Płuciennik M., Po(d)łaczeni. Empiryczne badania nad odbiorem literatury wobec odbioru cyfrowego, „Teksty Drugie” 2019, nr 5.

Rembowska-Płuciennik M., Poetyka intersubiektywności. Kognitywistyczna teoria narracji a proza XX wieku, Wydawnictwo Naukowe Uniwersytetu Mikołaja Kopernika, Toruń 2012.

Rembowska-Płuciennik M., Second-person Narration as a Joint Action, „Language and Literature" 2018, vol. 3.

Rembowska-Płuciennik M., Second-person Narration: A New Mode of (Mis)Understanding the Other?, w: Culture - Cognition - Communication, ed. J. Hood, Peter Lang, Frankfurt am Main 2018. 
Richardson B., "At First You Feel a Bit Lost”: The Varieties of Second Person Narration, w: idem, Unnatural Voices: Extreme Narrations in Modern and Contemporary Fiction, Ohio State University Press, Columbus 2006.

Spalińska-Mazur J., Śmierć oka. Gest przemocy w filmie Luisa Buñuela i Salvadora Dali „Pies andaluzyjski”, w: Stowo i gest, red. ks. H.J. Sobeczko, Z.W. Solski, Wydawnictwo i Drukarnia Św. Krzyża, Opole 2009, s. 319-326.

Strickland S., The Death and Re-Distribution of V, w: \#WomenTechLit, ed. M. Mencia, West Virginia University Press, Morgantown 2017, s. 417-426.

Szczęsna E., Cyfrowa semiopoetyka, IBL PAN, Warszawa 2018. 